not confirmed by figures of the student enrolments for 1966 to $1967-26$ per cent more students enrolled for courses leading to the council's first degrees in September 1967, compared with the number in 1966 . The 1967 figure is 167 per cent more than that for 1965 . The total number of students attending CNAA courscs this session is 10,687 , compared with 7,109 at the same time last year.

During 1966-67 the council approved fifty-four courses out of 136 proposed by colleges. Of the courses approved, forty-seven were in science and technology (50 per cent of the number considered) and seven in arts and social studies (17 per cent of the number considered). There are now 173 courses recognized by the council (as at September 1967) covering subjects ranging from aeronautical engineering, agricultural engineering, to textile technology and urban and regional planning. Most are sandwich courses-77 per cent of the courses in science and technology are of this type. One new course, of particular interest to some, is a part-time day and evening course in mathematics at Hatfield College of Technology which is designed especially for mature students.

A useful feature of the CNAA courses is that some are in fields where there are few or no courses in universities; degrees can now be obtained, for example, in building economics, estate management, food science, and photographic technology. The council also reports that it is considering librarianship and architecture as suitable fields for CNAA degrees. Since the report was written it is understood that a degree in information science has been approved by the council. It is to be offered by the Department of Librarianship at Newcastle College of Commerce as from September 1968. This course is designed primarily to preparc students to work in governmental and industrial information departments.

It is casy to forget that the council also has the power to award higher degrees. During 1966-67, five courses leading to the council's M.Sc. degree were approved, bringing the total number of CNAA postgraduate courses to seven-fifty-three students are enrolled on these. Two of the courses offered are in corrosion science and engineering and in expcrimental nuclear physics.

There is a growing number of registrations for the council's rescarch degrees, particularly from candidates in research organizations. The flexibility of the council's arrangements, and the absence of a residential requirement, seen to be proving attractive to many candidates not eligible for higher dogrees awarded by universities. The council's Ph.D. degree or M.C.T. (Membership of the College of Technologists) was awarded to twelve students during 1966-67. There are now 317 candidates registered for research degrees.

The council reports continuing good relations with the universities. Many organizations and professional bodies now give CNAA degrees the same recognition as they give to university degrees; for example, the Civil Service in its recruitment policies, and the Burnham committees in their acceptance of graduate qualifications for salary purposes.

It is inevitable that the council's activities are in. separable from the development of the polytechnics. In this connexion the council is continuing its efforts for now types of course, and broader courses combining more than one discipline-courses covering science and technology and social studies, which might be attractive to students who have read arts subjects in the sixth form at school.

\section{Visiting Fellows}

THE Senior Visiting Fellowship scheme of the Science Research Council is undergoing spring cleaning, and the revised regulations are likely to be published in the near future. As it stands at the moment, "the council will make grants to applicants of acknowledged standing to invite senior scientists of distinction in other research schools in this country or abroad to the investigator's institution as senior visiting fellows for a period not exceeding one year to give full-time advice and assistance to the investigator in the ficld in which the visitors are eminent". The fellowships were designed to bring expert outsiders into individual research projects when specific advice was required, and are therefore included in the research grant scheme. Despite criticism on this score, and suggestions that the visiting fellows should be treated in the same way as research fellows, it is unlikely that the new regulations will alter the grouping of the schemes.

People like Dr N. Kurti of Oxford are enthusiastic: about the possibilities of such a scheme, but regret that it has not received more publicity. Another criticism has been raised over the question of pay, because, as the regulations state, "if contributions to salary or expenses are being made by a senior visiting fellow's parent organization or other body, the charges to the grant will be reduced accordingly", This is thought to be an unfortunate arrangement, particularly for American visitors whose salary is paid on a nine-monthly basis but is considered to cover a year.

Until now, applications for senior visiting fellowships have had to be made on the same complicated forms as those for research grants. But here the criticism seems to have had some effect and the tidying up of the scheme will probably result in a shorter form being produced. It is thought unlikely that the improved scheme will be put before the council itself, which indicates that there is little hope for major changes. Mr L. S. Smith of the SRC has already stated that there will be no increase in the daily allowance for senior visiting fellows. During the year 1965-66, the last year for which figures are available, the council spent $\mathfrak{1 2 , 6 4 5}$ on fifty senior visiting fellowships-a. reduction of more than $£ 13,000$ compared with the year before.

\section{Changes at Cold Spring Harbor}

Tre Cold Spring Harbor Laboratory for Quantitative. Biology, famous for its annual symposia, its summer courses and for its year-round research in genetics, has recently been strengthened by the appointment of Dr J. D. Watson as director from February 1 of this year. Dr Watson seems to have been persuaded to take on the job, while remaining as Professor of Biochemistry and Molecular Biology at Harvard, by his wish to see that the laboratory's dramatic improvement from a state of financial and physical bankruptey would not come to a halt now that Dr John Cairns, the current director, had chosen to concentrate once again 